\title{
Contamination assessment of surface and groundwater within and around two dumpsites
}

\author{
${ }^{1 *}$ A. M. Odukoya; ${ }^{2}$ A. F. Abimbola \\ ${ }^{1}$ Department of Geosciences University of Lagos , Lagos, Nigeria \\ ${ }^{2}$ Department of Geology University of Ibadan, Oyo, Nigeria
}

Received 16 January 2010; revised 5 February 2010; accepted 28 February 2010; avaiable online 1 March 2010

\begin{abstract}
Geochemical analyses of groundwater and streams flowing around abandoned and active dumpsites in Lagos, Southwestern Nigeria were carried out. Results show that water samples have generally low total dissolved solids with average values of 163.75 and 153.4 for abandoned and active dumpsites, respectively. $\mathrm{pH}$ ranges from 3.968.34 while total hardness varies from $10-220 \mathrm{mg} / \mathrm{L}$ calcium carbonate (soft to slightly hard). Average concentrations of the dominant ions for abandoned and active dumpsites were 57.8 and $25.86 \mathrm{mg} / \mathrm{L}(\mathrm{Na})$ representing 40.7 and $46.3 \%$ of the total cations respectively and Nitrate (av. 96.89 and $61.51 \mathrm{mg} / \mathrm{L}$ ) representing $49.1 \%$ and $40 \%$, respectively of the total anions. The $\mathrm{pH}$, coliform count and concentrations of nitrate iron, manganese and sodium in most of the water samples were above the national drinking water standards proposed by the United States Environmental Protection Agency. Trace elements like silver, arsenic, beryllium, bismuth, cerium, cobalt, chromium, lithium selenium, tellurium, titanium, uranium, vanadium, tin and yttrium were below detection level for all the water samples while tungsten, thallium, molybdenum and lead were only present in surface and groundwater close to the dumpsites and also display values higher than recommended standards while cupper, zinc, aluminum, barium and strontium were present in most of the samples. The pollution index among all sites varied from 0.009 to 1.26 and 0.106 to 6.25 for abandoned and active dumpsites, respectively while the water around most of the dumpsite areas exceeded the acute and chronic effect levels proposed by the United States Environmental Protection Agency in 2007.
\end{abstract}

Keywords: Anthropogenic; Environment; Pollution index; Trace elements

\section{INTRODUCTION}

The disposal of wastes generated by human activities within a municipality is generally an urban problem. The recognition of the connection between human activities and pollution and the need to protect human health, recreation and fisheries production led to the early development of water quality regulations and monitoring methods (Hem 1985; Jenkins et al., 1996; USEPA, 2007). The existence of trace metals in aquatic environments has led to serious concerns about their influence on plant and animal life (Samarghandi et al., 2007; Zvinowanda et al., 2009). During their transport, the trace metals undergo numerous changes in their speciation due to dissolution, precipitation, sorption and complexation phenomena (Akcay et al., 2003; Abdel-Ghani and Elchaghaby, 2007; Abdel-Ghani et al., 2009; Mohinddin et al., 2010). One of the reasons these toxins are so harmful is that they become more 凶*Corresponding Author Email: sesanbiodun@yahoo.com Tel./Fax: +0805 6272219 concentrated in successive trophic levels of a food web, a process called biological magnification (Woodwell, 1972; Grimanis et al., 1978; Adams et al., 1992; Campbell, 1996; Manly, 1996; Kaonga et al., 2010). The need for socio-economic advancement has led to rapid expansion of the industrial sector in developing countries like Nigeria. These waste disposal sites and landfills are neither properly designed nor constructed. After some years a dumpsite undergoes biologically, chemically, geologically and hydro geologically mediated changes resulting in a weathering process consequently, it becomes point source for pollution of the aquiferous units close to them (Arienzo et al., 2001; Manjunatha et al., 2001; Altindag and Yigit, 2005; Awofolu et al., 2005; Wang and Zhuo, 2005; Adeniyi et al., 2008). The commonly used disposal methods of the solid wastes in the study area are open dumps, non-engineering sanitary landfill and incineration. When rain falls, the rain leaches pollutants from the 
waste disposal sites. Thus introducing toxins and contaminants into the soil, surface and groundwater and eventually plants that grow within the vicinity of the dumpsite (Awofolu et al., 2007; Daka et al., 2007). The overall implication of this is that the hydrochemical facies of groundwater changes in response to its flow path history, that is, underground water quality is dependent on pollution status of its environment (Olabaniyi and Owoyemi, 2006).

\section{Geological and geomorphologic features}

The geology of the study area fall within coastal plain sand of Dahomey Basin and is characterized by coarse, unsorted sands and clay lenses mixed together in varying proportions at varying depth. Depth to water ranges from land surface to about $10 \mathrm{~m}$ for first aquifer. Generally, the lithology is composed of medium to coarse grained sandy horizon interbedded with thin band of grey black clay which occur in minor proportion $(<20 \mathrm{~m})$.

The study areas which are Isolo and Ojota dumpsites are both located in Lagos, southwestern
Nigeria (Fig. $1 \mathrm{a}$ and b). Ojota disposal site is located in the northeastern area of Lagos. It is very massive with a topographical height of about $45.45 \mathrm{~m}$ (150 ft) from the sea level it has been in operation since 1992, still very active and it is very close to so many industries. The Isolo waste disposal site is situated at the northern part of Lagos metropolis. It is sited very close to a big canal which normally overflows its banks during the rainy season and a dominant percentage of the waste deposited here are domestic wastes. Also, the site has been abandoned for the past twelve years and therefore, it is no more active. This research has been done between 2007 and 2008.

\section{MATERIAL AND METHODS}

Water samples from boreholes, wells and streams were collected at several locations within and around the two dumpsites. Several sensitive parameters of water such as total dissolved solids (TDS), electrical conductivity and $\mathrm{pH}$ were determined during the on the spot sampling using the appropriate digital meters (e.g. water treatment works (WTW)-conductivity meter
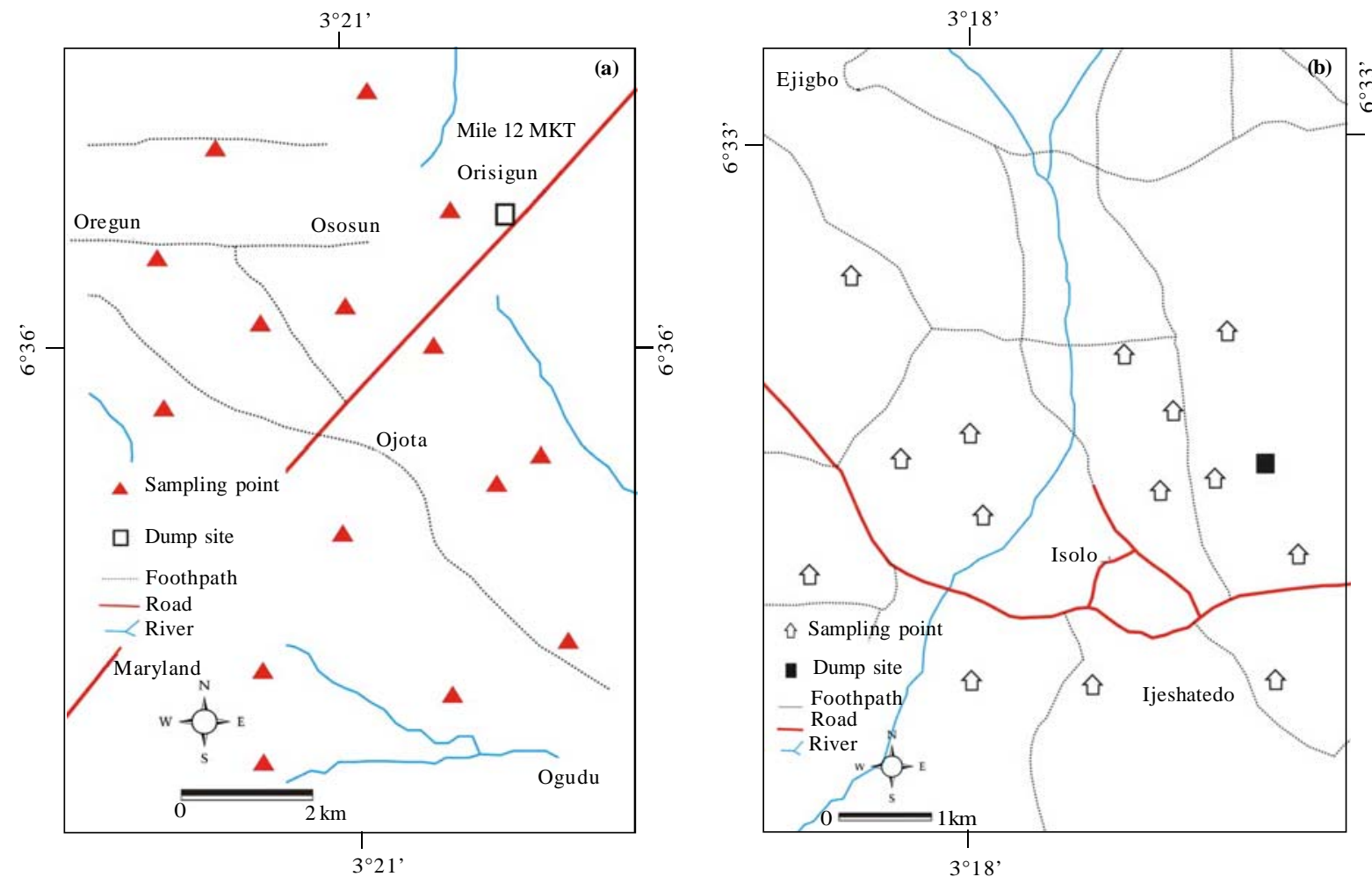

Fig. 1: Sample locations for a) Active dumpsite; b) Abandoned dumpsite 
model L/92 and WTW- $\mathrm{pH}$ meter model $\mathrm{pH} / 91$ ). Water samples of approximately $125 \mathrm{~mL}$ were collected for multielement analysis; pressure filtered through $0.2 \mathrm{~mm}$ Nuclepore membranes and $3 \mathrm{~mL}$ analytical grade $\mathrm{HNO}_{3}$ was added to bring the water acid solution to a $\mathrm{pH} \sim 2$. The analysis of trace elements and cations in water were carried out using inductively coupled plasmaoptical emission spectrometry (ICP-OES) while unacidified water samples were analyzed for anions concentrations using the DIONEX DX-120 ion chromatography techniques. All the analyses were carried out at the Actlabs laboratory, Ontario Canada. To check the accuracy, activation laboratories (Ontario, Canada) employed two internal standards (each run twice) and found that the errors were consistently minimal. Bacteriological analysis of the water samples was also carried out. Results were further compared with recommended standards and pollution index was calculated to determine the impacts of the two dumpsites on water quality.

\section{RESULTS AND DISCUSSION}

The summary of the concentrations of dissolved elements in streams and groundwater around both active and abandoned dumpsites in Lagos, Southwestern Nigeria were given together with national drinking water standards proposed by the US Environmental Protection Agency (USEPA) in may 2009 (Tables 1 and 2). pH values range from 3.96-8.34 with most of the samples slightly acidic and out of the USEPA (2009) standards as a result of dilution by leachates. Total dissolved solid is low generally with mean values of 163.62 and 153.38 while electrical conductivity (EC) showed mean of 301.63 and 311.21 for abandoned and active dumpsites, respectively. On this basis, the water can be classified as fresh (Todd, 1980). Major ions such as $\mathrm{Fe}, \mathrm{Mg}, \mathrm{Mn}, \mathrm{Na}, \mathrm{Br}$ and $\mathrm{NO}_{3}$ in the water samples were higher than the limits of the above standards for samples close to the dumpsites, (Fig. 2). Concentrations for $\mathrm{Au}, \mathrm{Be}, \mathrm{Hg}$, In, Ir, Nb, Os, $\mathrm{Pd}, \mathrm{Pt}, \mathrm{Re}, \mathrm{Rh}, \mathrm{Ru}, \mathrm{Sb}, \mathrm{Se}, \mathrm{Ta}$ and Te were all below the detection limit for ICP-OES and therefore were not listed in Tables 1 and 2. The metals showed the following trends $\mathrm{Zn}>\mathrm{Al}>\mathrm{Sr}>\mathrm{Ba}>\mathrm{Cu}>\mathrm{Ni}$ and $\mathrm{Zn}>$ $\mathrm{Al}>\mathrm{Ni}>\mathrm{Sr}>\mathrm{Ba}>\mathrm{Cu}$ for abandoned and active dumpsites respectively. The mean concentrations for samples taken around abandoned and active dumpsites were 551.5 and 398.76 for $\mathrm{Zn}, 4.71$ and 72.06 for $\mathrm{Ni}, 52.35$ and 43.76 for $\mathrm{Ba}, 32.59$ and 15.29 for $\mathrm{Cu}$,
182.4 and 264.7 for $\mathrm{Al}$ and 0.18 and 137.6 and 57.65 for $\mathrm{Sr}$, respectively (Tables 1 and 2). W, Mo and $\mathrm{Pb}$ were found only in the two samples and both were above USEPA, 2009 standards. $\mathrm{NO}_{3}$ ranges between $0.3-250.3$ $\mathrm{mg} / \mathrm{L}$ and $3.2 \mathrm{mg} / \mathrm{L}-200 \mathrm{mg} / \mathrm{L}$ while coliform ranges between $0 \mathrm{cfu} / 100 \mathrm{~mL}-600 \mathrm{cfu} / 100 \mathrm{~mL}$ and $10 \mathrm{cfu} / 100$ $\mathrm{mL} 600 \mathrm{cfu} / 100 \mathrm{~mL}$ for abandoned and active dumpsites, respectively. The large relative standard deviation values indicate that there is significant variability among the individual sampling sites around the two dumpsites. The wide range of concentrations most likely represents different point-source inputs from different materials in the dumpsites since chemical weathering of sedimentary rocks which is Coastal Plain Sands in the case of the study area are unlikely to provide such large spatial fluctuations in trace elements content. The variability of concentrations of these elements, as well as total coliform within the water suggests local anthropogenic input sources through domestic, municipal and industrial wastes within the dumpsites. The total concentrations of the elements were compared at several sampling sites and there was a slight overall trend of increase in the concentration of trace and major elements in the water samples within and very close to the dumpsites (Figs. 3 and 4). The large increase at these sites suggests a high elemental input into the water which is probably from the dumpsites. Leachate within the two dumpsites showed the highest values for most of the elements while the control samples taken far away from the sites showed the least (Figs. 3 and 4).

\section{Pollution index}

The pollution index was used in this study to evaluate the degree of trace metal contamination (Nishida et al., 1982; Chon, et al., 1991; Kim et al., 1998; Emoyan et al., 2005; Nier 2007). The tolerable level is the element concentration in the water considered safe for human consumption (Kloke 1979; Lee et al., 1998). The USEPA national drinking water standards (2009) were used as tolerable level for water and the pollution index can be calculated by the formulae below

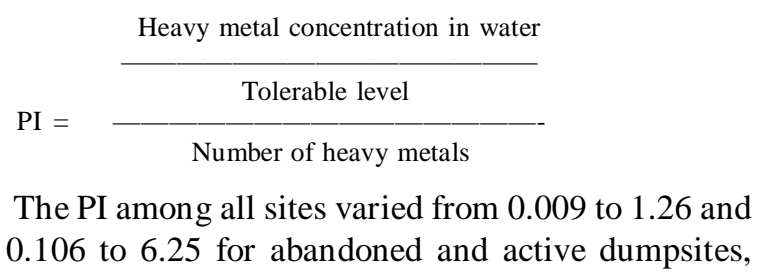


Quality of water around dumpsiteg

Table 1: Summary of results of water samples within and around abandoned dumpsite

\begin{tabular}{|c|c|c|c|c|c|}
\hline & Surface water & Groundwater & Leachate & Control & NDWS \\
\hline $\mathrm{pH}$ & $4.5-8.34(4.72)$ & $3.96-8.05(5.54)$ & 6.57 & 7.8 & $6.5-8.5$ \\
\hline Conductivity & $170-250(226.25)$ & $40-730(255.2)$ & 665 & 50 & 1400 \\
\hline TDS & $116-186(164.75)$ & 26-453(168.9) & 408 & 30 & 1000 \\
\hline Hardness & $10-48(29.25)$ & $20-220(69.4)$ & 70 & 67 & \\
\hline Total coliform & $10-420(161.5)$ & $0-600(98.8)$ & 205 & 10 & 0 \\
\hline $\mathrm{Ca}$ & $9.2-128(44.9)$ & $1.2-45(14.85)$ & 43.6 & 81.1 & 200 \\
\hline $\mathrm{Fe}$ & $0.05-0.23(0.13)$ & $0.03-0.34(0.095)$ & 0.47 & 0.01 & 0.3 \\
\hline $\mathrm{K}$ & 7.4-194(56.85) & $0.3-12.4(4.025)$ & 6.7 & 1.9 & \\
\hline $\mathrm{Mg}$ & 3-63.1(18.25) & $0.5-43.2(6.98)$ & 2.2 & 6 & 50 \\
\hline $\mathrm{Mn}$ & $0.09-0.16(0.12)$ & $0.02-0.14(0.07)$ & 0.06 & 0.01 & 0.05 \\
\hline $\mathrm{Na}$ & 27.7-243(97.8) & 4.2-84(29.7) & 34.8 & 4.9 & 200 \\
\hline $\mathrm{P}$ & $0.82-3.76(2.3)$ & $0.22-2.24(0.84)$ & 1.22 & 0.04 & \\
\hline $\mathrm{Si}$ & $2.4-10.3(5.6)$ & $2.5-8.4(5.05)$ & 8.5 & 7.6 & \\
\hline $\mathrm{S}$ & $5-24(14.5)$ & $1-22(4.03)$ & 9 & 5 & \\
\hline $\mathrm{Cl}$ & 28.6-406(128.7) & $12.8-29.8(21.54)$ & 91.8 & 34 & 230 \\
\hline $\mathrm{Br}$ & $0-0.61(0.18)$ & ND-0.61(0.177) & 0.19 & 0.04 & 0.01 \\
\hline $\mathrm{NO}_{3}$ & $0.03-250.3(135.96)$ & $0.02-120.3(39.8)$ & 110.1 & 0.01 & 10 \\
\hline $\mathrm{SO}_{4}$ & 3.07-187(51.46) & $1.13-76.4(29.69)$ & 31.1 & 2.81 & 400 \\
\hline $\mathrm{HCO}_{3}$ & $0-38(12)$ & $0-25(6.3)$ & 78 & 45 & \\
\hline Al & $200-1100(400)$ & ND-300(90) & 300 & 100 & 87 \\
\hline $\mathrm{Ba}$ & $40-100(65)$ & $40-100(49)$ & 80 & 40 & 1 \\
\hline $\mathrm{Cu}$ & $4-46(21.5)$ & $8-232(43.6)$ & 16 & 4 & 1 \\
\hline $\mathrm{Ni}$ & $0-20(7.5)$ & ND-15(3.5) & 10 & nd & 0.02 \\
\hline $\mathrm{Zn}$ & $525-1060(791.25)$ & $30-960(384.6)$ & 2330 & 30 & 5 \\
\hline $\mathrm{Sr}$ & $50-670(227.5)$ & 20-520(105) & 120 & 250 & 0.01 \\
\hline
\end{tabular}

Table 2: Summary of results of water samples within and around active dumpsite

\begin{tabular}{|c|c|c|c|c|c|}
\hline & Surface water & Groundwater & Leachate & Control & NDWS \\
\hline pH & $4.28-6.75(5.1)$ & $4.23-8.04(5.64)$ & 4.89 & 7.92 & $6.5-8.5$ \\
\hline Conductivity & $122-603(302.6)$ & $122-703(340.9)$ & 50 & 30 & 1400 \\
\hline TDS & 24-185(128.4) & 86-424(197.3) & 25 & 25 & 1000 \\
\hline Hardness & 10-65(37) & 22-102(51.2) & 210 & 75 & \\
\hline Total coliform & 12-308(111) & 10-308(90.3) & 208 & 5 & 0 \\
\hline $\mathrm{Ca}$ & $2.3-23.1(12.16)$ & 2.4-17.9(6.83) & 8.5 & 81.1 & 200 \\
\hline $\mathrm{Fe}$ & $0.04-2.36(0.52)$ & $0.02-1.32(0.18)$ & 0.06 & 0.01 & 0.3 \\
\hline K & 1.2-21.7(9.1) & 1-20.6(6.17) & 5.5 & 1.9 & \\
\hline Mg & $0.5-3.9(2.32)$ & $0.6-3.5(1.43)$ & 1.6 & 6 & 50 \\
\hline Mn & $0.02-0.21(0.1)$ & $0.03-0.14(0.06)$ & 0.06 & 0.01 & 0.05 \\
\hline $\mathrm{Na}$ & $13.2-75.6(38.62)$ & $13.4-56.7(26.08)$ & 33.6 & 4.9 & 200 \\
\hline $\mathrm{P}$ & $0.34-3.64(1.99)$ & $0.02-2.32(0.86)$ & 2.8 & 0.04 & \\
\hline $\mathrm{Si}$ & $4.4-9.6(6.56)$ & $1.7-8.7(4.7)$ & 4.7 & 7.6 & \\
\hline $\mathrm{S}$ & 5-19(10.8) & $2-17(6.8)$ & 11 & 5 & \\
\hline $\mathrm{Cl}$ & $12.5-54(44.95)$ & $5.06-78.2(38.2)$ & 87.2 & 34 & 230 \\
\hline $\mathrm{Br}$ & ND & ND & ND & ND & 0.01 \\
\hline $\mathrm{NO}_{3}$ & 3.2-117.9(79.13 & $2.41-200.01(51.62)$ & 217.5 & 0.01 & 10 \\
\hline $\mathrm{SO}_{4}$ & $1.29-7.09(4.13)$ & $1.19-9.86(4.3)$ & 7.09 & 2.81 & 400 \\
\hline $\mathrm{HCO}_{3}$ & $0-103(20.5)$ & $0-213(24.45)$ & 0 & 45 & \\
\hline $\mathrm{Al}$ & $200-600(300)$ & 200-400(290) & 200 & 100 & 87 \\
\hline $\mathrm{Ba}$ & $40-100(72)$ & ND-80(56) & 35 & 40 & 1 \\
\hline $\mathrm{Cu}$ & $10-24(14.4)$ & $8-26(17.1)$ & 28 & 4 & 1 \\
\hline $\mathrm{Ni}$ & nd-19(6) & Nd-540(65.5) & 600 & Nd & 0.02 \\
\hline $\mathrm{Zn}$ & 240-645(405) & 260-895(402 & 1100 & 30 & 5 \\
\hline Sr & $20-80(58)$ & $20-100(44.4)$ & 30 & 250 & 0.01 \\
\hline
\end{tabular}

*NDWS: National drinking water standards, *ND: Not detected, ${ }^{*}$ Major elements in $\mathrm{mg} / \mathrm{L},{ }^{*}$ Trace elements in $\mu \mathrm{g} / \mathrm{L}$ 

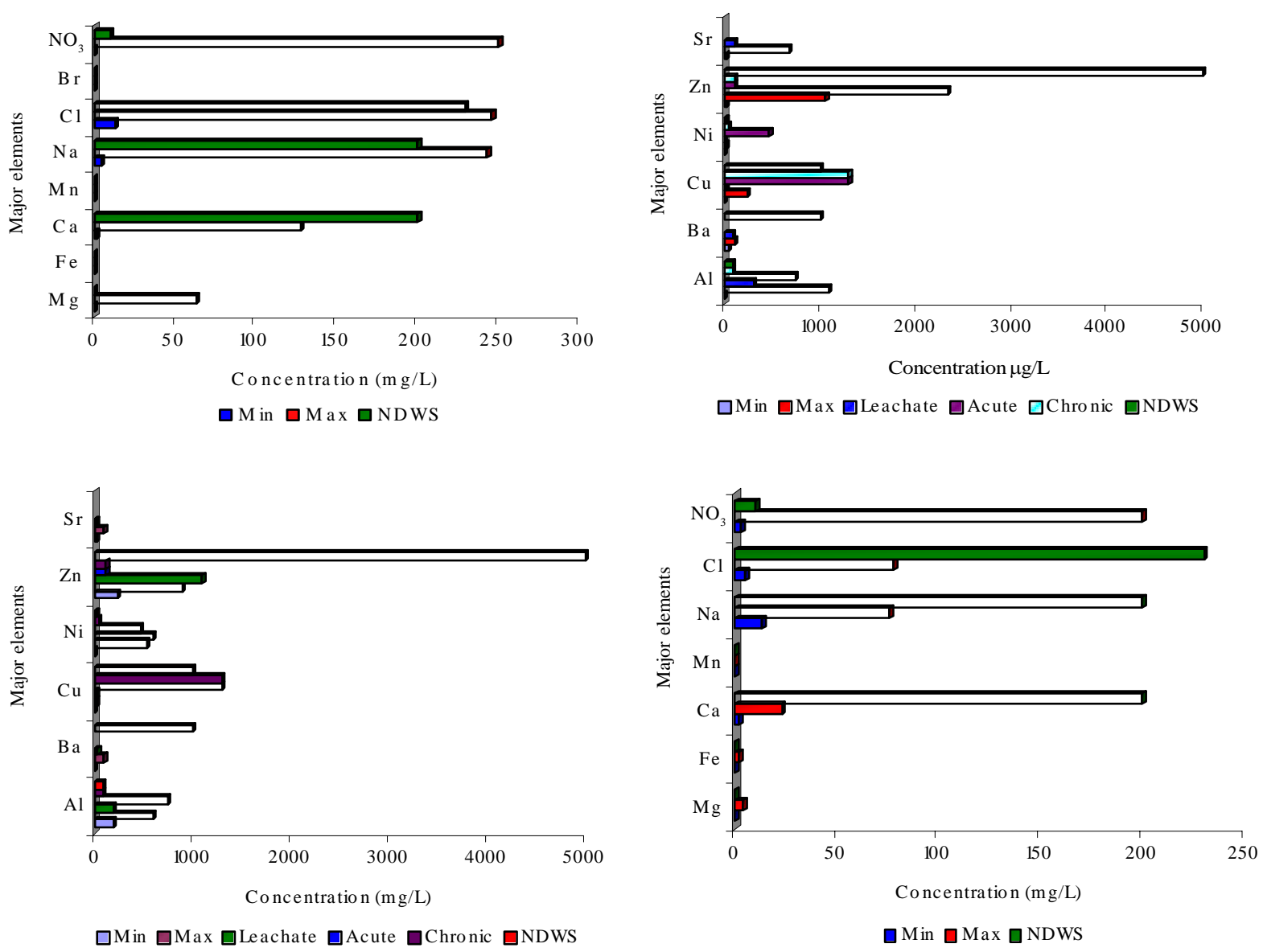

Fig. 2: Bar charts of heavy metals and some major elements concentration with acute, chronic and national drinking water standards proposed by USEPA (2009)

respectively. Concentrations of $\mathrm{Al}, \mathrm{Ba}, \mathrm{Cu}, \mathrm{Zn}$ and $\mathrm{Sr}$ in most of the water samples were less than the given tolerable levels while Ni showed higher concentration in 1 and 2 samples for abandoned and active dumpsites, respectively (Figs. 5 and 6). Pi was below 0.1 at 4 and 6 samples representing ( $27.7 \%$ and $37.5 \%$ ) of the total samples, between 0.1 to 0.3 at 6 and 8 samples (37.5\% and $50 \%$ ) and greater than 0.3 at 5 and 2 samples (33.3\% and $12.5 \%$ ) for abandoned and active dumpsites, respectively (Table凹). The pollution index for shallow well and leachate within the active dumpsite were as high as 5.42 and 6.05, respectively.

\section{Fresh water acute and chronic criteria}

The water around most of the dumpsite areas exceeded the acute and chronic effect levels proposed by the US Environmental Protection Agency (USEPA) in 2007 (Fig. 1). The tolerable acute and chronic levels for fresh water are 470 and $52 \mu \mathrm{g} / \mathrm{L}$ for Ni, 750 and 87 $\mu \mathrm{g} / \mathrm{L}$ for $\mathrm{Al}, 13$ and $9 \mu \mathrm{g} / \mathrm{L}$ for $\mathrm{Cu}, 65$ and $2.5 \mu \mathrm{g} / \mathrm{L}$ for $\mathrm{Pb}$ and $120 \mu \mathrm{g} / \mathrm{L}$ for both, for $\mathrm{Zn}$. Among all the studied areas, $6.25 \%, 84.38 \%, 71.87 \%$ and $81.25 \%$ of water exceeded the acute and chronic limit of $\mathrm{Ni}$, $\mathrm{Al}, \mathrm{Cu}$ and $\mathrm{Zn}$, respectively. For chloride only one sample from surface water exceeded the fresh water aquatic life acute and chronic criteria. The standard recommended for the consumption of water and organisms for human health by USEPA (2007) include $300 \mathrm{ug} / \mathrm{L}, 50 \mathrm{ug} / \mathrm{L}$ and 10,000 ug/L for Fe, $\mathrm{Mn}$ and $\mathrm{NO}_{3}$ while $31.25 \%$, $46.88 \%$ and $59.4 \%$ of total samples exceeded these values, respectively. The source of these metals may be attributed to anthropogenic activities from the various wastes at the dumpsites and dumping of wastes/rubbish on the stream channels. The environmental implication of water contamination lies in the fact that the adsorbed portion 
A. M. Odukoya; A. F. Abimbola
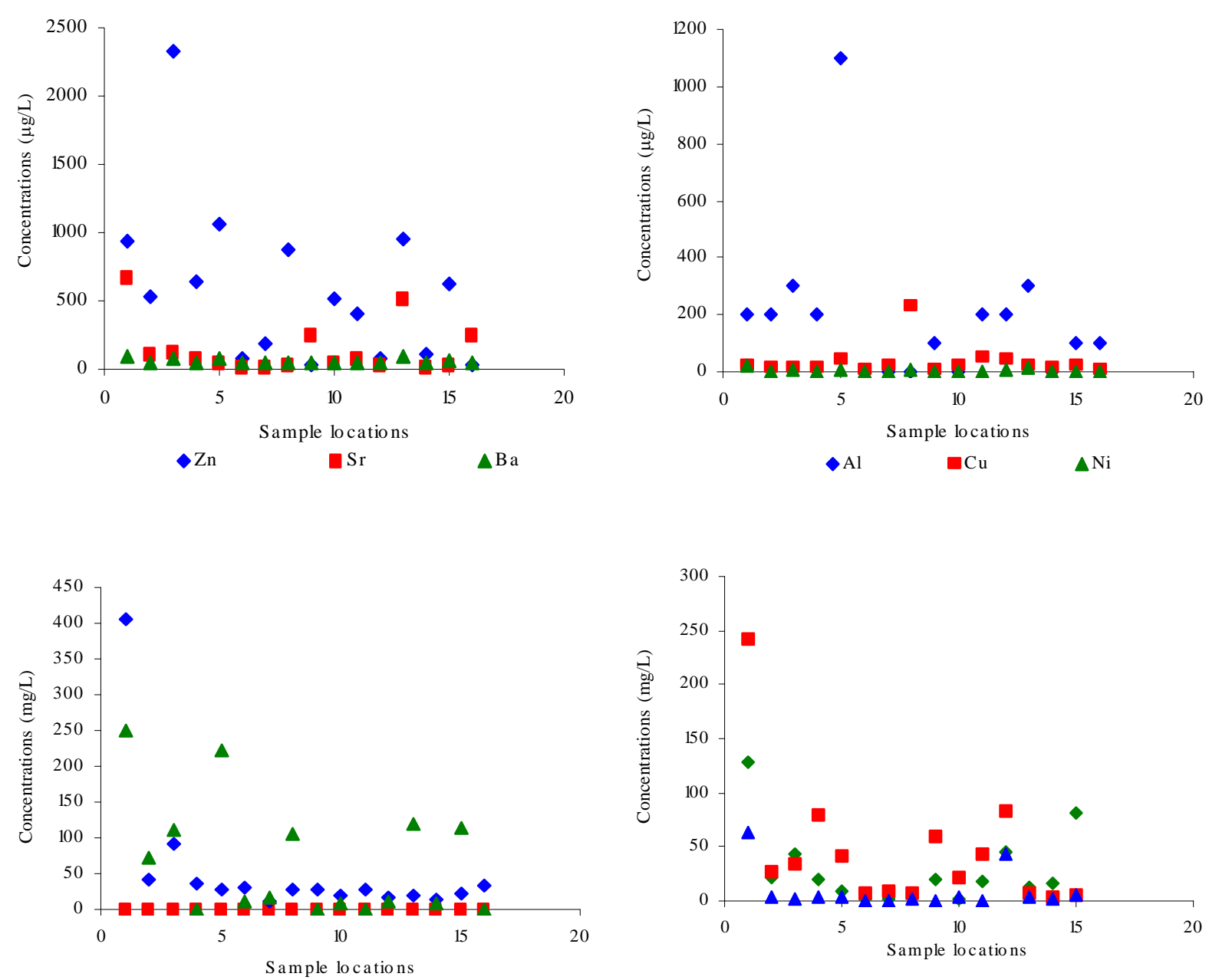

- $\mathrm{Cl} \quad \mathrm{Br} \Delta \mathrm{NO} 3$

$\diamond \mathrm{Ca} \quad \Delta \mathrm{Na}$
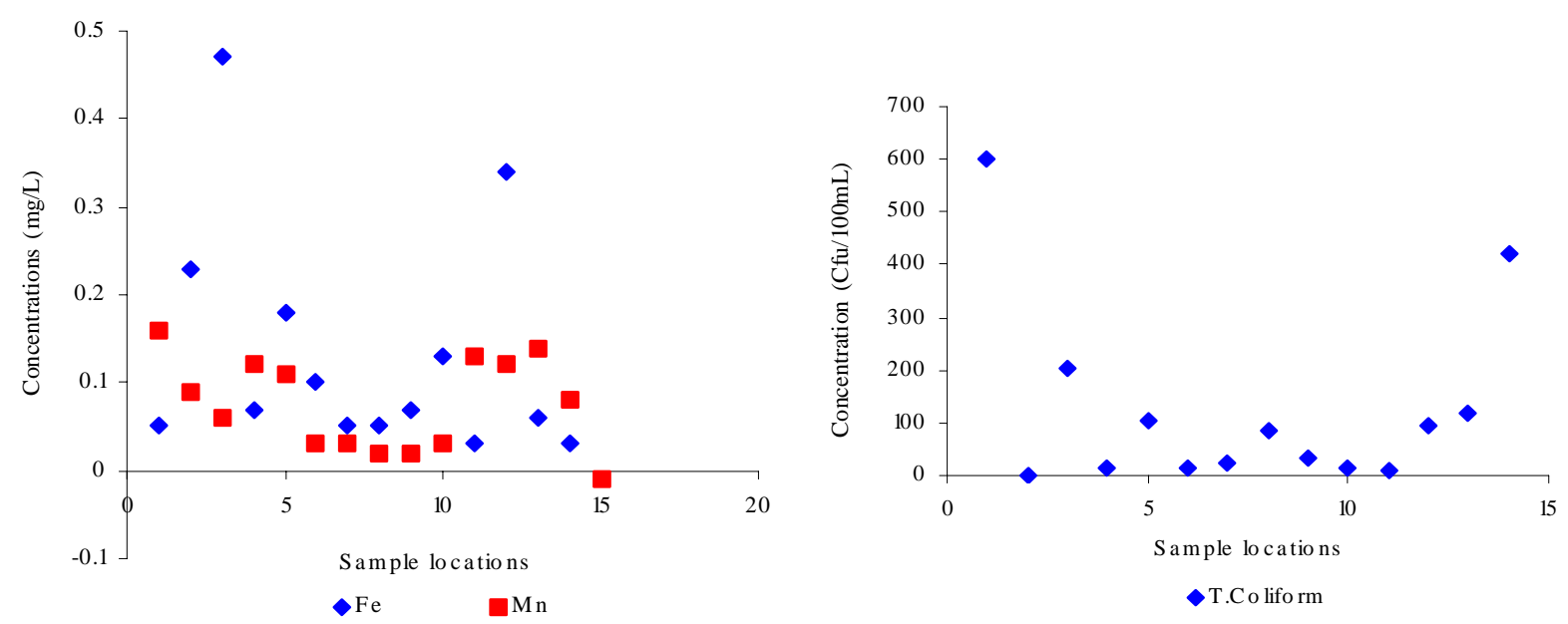

Fig. 3: Scattered plots of heavy metals against sample locations around abandoned dumpsite 
Int. J. Environ. Sci. Tech., 7 (2), 367-376, Spring 2010
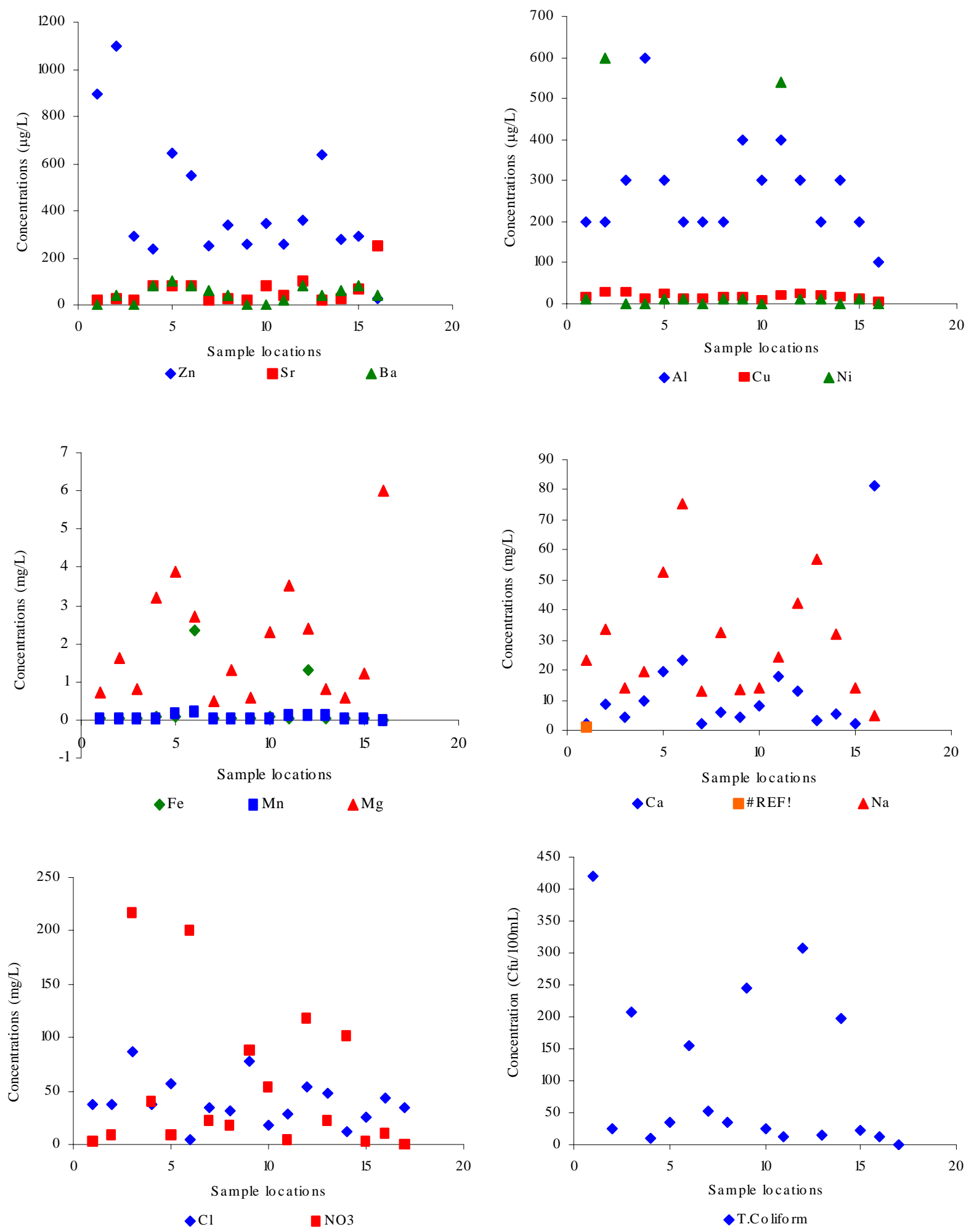

Fig. 4: Scattered plots of heavy metals against sample locations around active dumpsite 


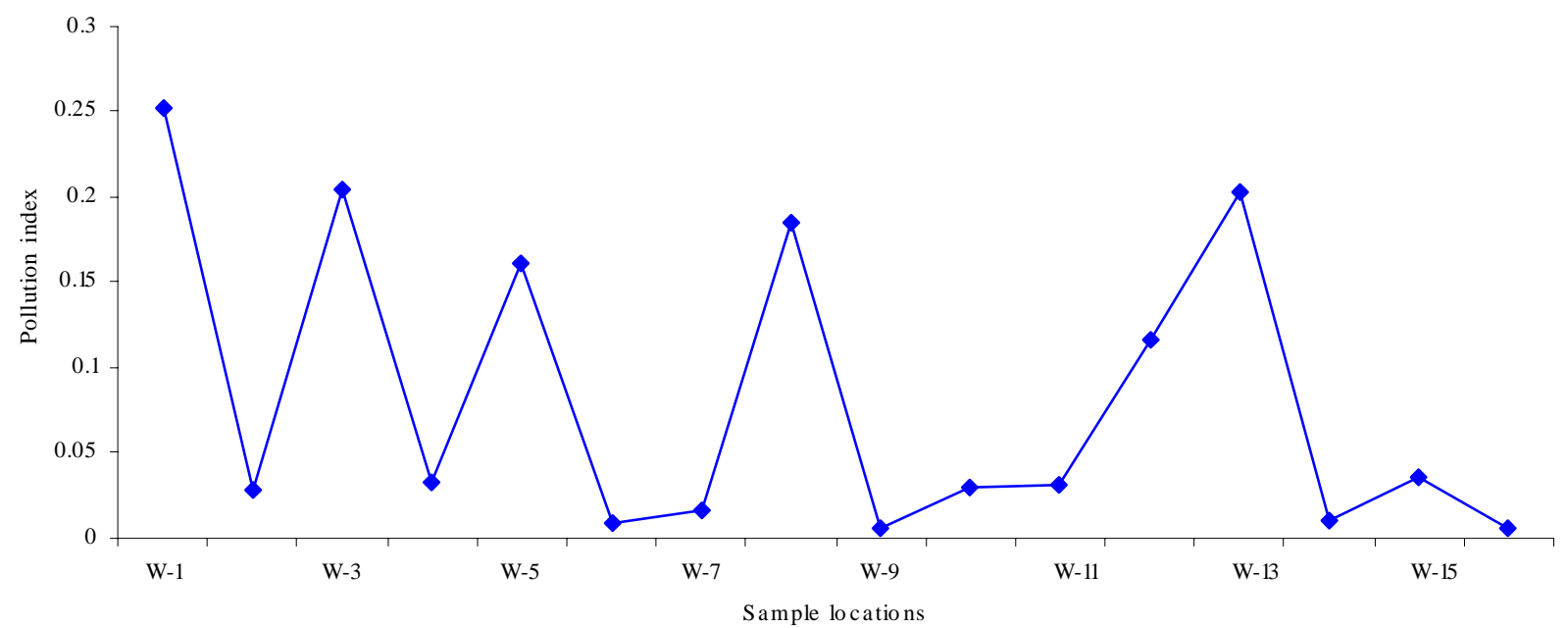

Fig. 5: Pollution index for abandoned dumsite

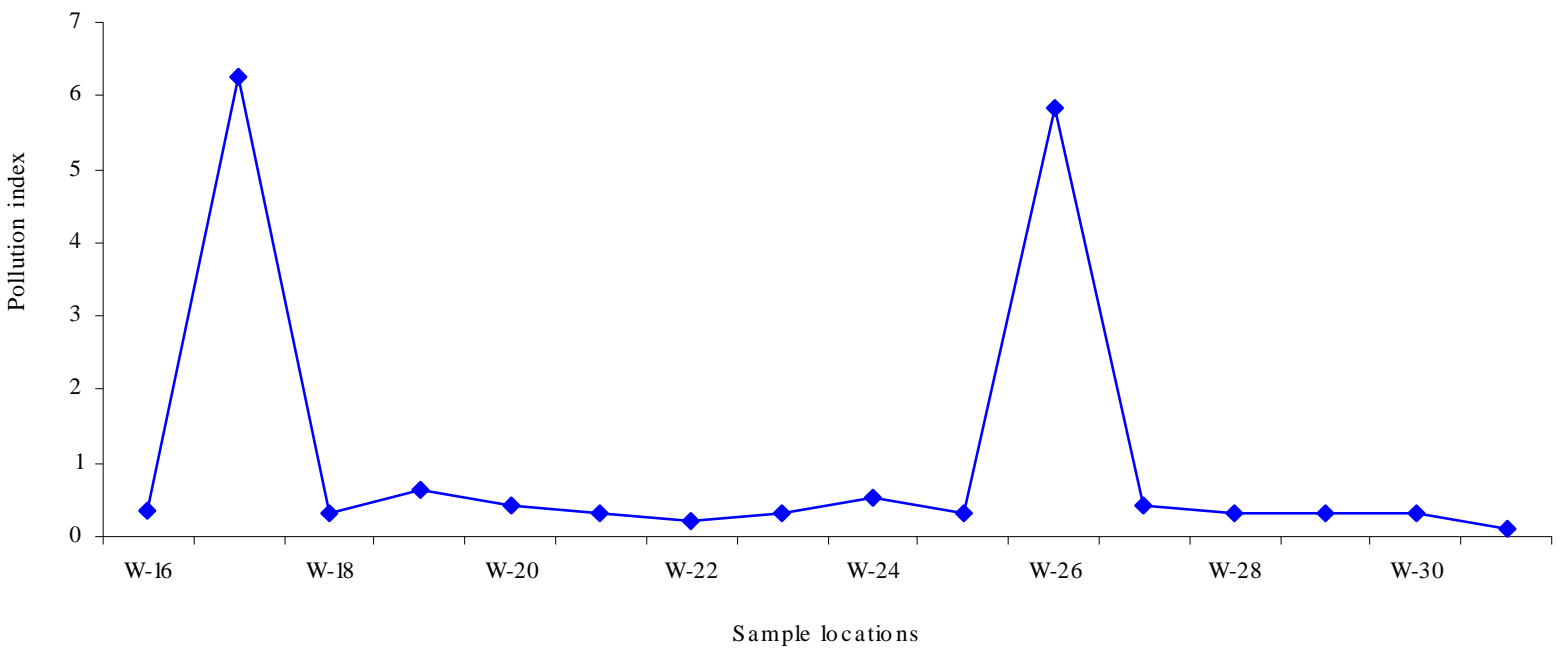

Fig. 6: Pollution index for active dumsite

of these metals will pollute the water which serves as source of drinking water for some people while the possible trophic transfers especially at the downstream outside the urban areas where local inhabitants use the water in vegetable nurseries/ farming call for concerns.

\section{CONCLUSION}

Quality evaluation of surface and groundwater from Lagos Southwestern Nigeria, were discussed as a case study of anthropogenic influence of dumpsites in a typical urban environment of a developing country. From this study, it is clearly evident that lack of well constructed environmental friendly landfills and indiscriminate dumping of wastes to stream channels have considerable influences on the heavy metal contaminations of surface and groundwater in the study area. The study revealed slight degree contamination of $\mathrm{Al}, \mathrm{Zn}, \mathrm{Ba}, \mathrm{Cu}, \mathrm{B}, \mathrm{Pb}, \mathrm{Mo}, \mathrm{W}$ and $\mathrm{Ni}$ in the some water samples around the two dumpsites compared to the USEPA (2009) standards. Among the major elements, $\mathrm{NO}_{3}$ and $\mathrm{Fe}$ are the most critical in the water system. Also, total coliform counts were very high in all the samples. The pollution index among all sites varied from 0.009 to 1.26 and 0.106 to 6.25 for abandoned and active dumpsites, respectively while the water around most of the dumpsite areas exceeded the acute and chronic effect levels proposed by the US Environmental Protection Agency (USEPA, 2007). 
Generally, the water contamination is related to anthropogenic sources mostly from different wastes within the dumpsites which are domestic/municipal and slightly industrial in origin.

\section{ACKNOWLEDGEMENTS}

The authors wish to acknowledge the financial support of the Vice Chancellor of Olabisi Onabanjo University, Ago Iwoye, Nigeria between 2001 and 2006.

\section{REFERENCES}

Abdel-Ghani, N. T.; Elchaghaby, G. A., (2007). Influence of operating conditions on the removal of $\mathrm{Cu}, \mathrm{Zn}, \mathrm{Cd}$ and $\mathrm{Pb}$ ions from wastewater by adsorption. Int. J. Environ. Sci. Tech., 4 (4), 451-456 (6 pages).

Abdel-Ghani, N. T.; Hegazy, A. K.; El-Chaghaby, G. A., (2009). Typha domingensis leaf powder for decontamination of aluminium, iron, zinc and lead: Biosorption kinetics and equilibrium modeling. Int. J. Environ. Sci. Tech., 6 (2), 243-248 (6 pages).

Adams, W. J.; Kimerle, R. A.; Barnet, J. W., (1992). Sediment quality and aquatic life assessment. Environ. Sci. Tech., 26 (10), 1865-1875 (11 pages).

Adeniyi, A. A.; Yusuf, O. O.; Okedeyi, O. O., (2008); Assessment of the exposure of two fish species to metals pollution in the Ogun river catchments, Ketu, Lagos, Nigeria. Environ. Monit. Assess., 137 (1-3), 451-458 (8 pages).

Akcay, H.; Oguz, A.; Karapire, C., (2003). Study of heavy metal pollution and speciation in Buyak Menderes and Gediz river sediments. Water Res., 37 (4), 813-822 (10 pages).

Altindag, A.; Yigit, S., (2005). Assessment of heavy metal concentrations in the food web of lake Beysehir, Turkey. Chemosphere, 60 (4), 552-556 (5 pages).

Arienzo, M.; Adamo, P.; Bianco, M. R.; Violante, P., (2001). Impact of land use and urban run-off on the contamination of the Samo river basin in southwestern Italy. Water Air Soil Pollut., 131 (1-4), 349-366 (18 pages).

Awofolu, O. R.; Du Plessis, R.; Rampedi, I., (2007). Influence of discharged effluent on the quality of surface water utilized for agricultural purposes. Afr. J. Biotech., 6 (19), 22512258 (8 pages).

Awofolu, O. R.; Mbolekwa, Z.; Mtshemla, V.; Fatoki, O. S.; (2005). Levels of trace metals in water and sediment from Tyume river and its effects on an irrigated farmland. Water S. Afr., 31 (1), 87-94 (8 pages).

Campbell, N. A., (1996). Biology, $4^{\text {th. }}$ Ed. The Benjamin/ cummings publishing company Inc., University of California, USA.

Chon, H. T.; Ahn, J. S.; Jung, M. C., (1991). Environmental contamination of toxic heavy metals in the vicinity of some $\mathrm{Au}-\mathrm{Ag}$ mines in Korea. Proc. of the $4^{\text {th. }}$ Biennial SGA Meeting, Truku: Finland, 891.

Daka, E. R.; Molson, M.; Ekeh, C. A.; Ekweozor, I. K. E., (2007). Sediment quality status of two creeks in the upper bonny estuary, Niger delta, in relation to urban/industrial activities. Bull. Environ. Contam. Toxicol., 78 (6), 515521 (7 pages).
Emoyan, O. O; Ogban, F. E.; Akarah, E., (2005). Evaluation of Heavy metals loading of River Ijana, Nigeria. J. Appl. Sci. Environ. Manag., 10 (2), 121-7 (7 pages).

Grimanis, A. P.; Zafiropoulos, D.; Vassilaki, R.; Grimanis, M., (1978). Trace elements in the flesh and liver of two fish species from polluted and unpolluted areas in the Aegean Sea. Environ. Sci. Tech., 12 (6), 723-726 (4 pages).

Hem, J. D., (1985). Study and interpretation of the chemical

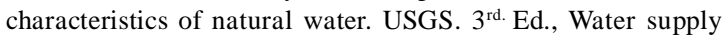
paper, 2254.

Jenkins, P.; Southern, T.; Truesdale, V.; Jeary, A., (1996). Waters. Watts S., Halliwell L., (Eds.). Essential environmental science. Methods and Techniques London: Routledge, 336-350.

Kaonga, C. C.; Kumwenda, J.; Mapoma, H. T., (2010). Accumulation of lead, cadmium, manganese, copper and zinc by sludge worms; Tubifex tubifex in sewage sludge. Int. J. Environ. Sci. Tech., 7 (1), 119-126 (8 pages).

Kim, K. W.; Lee, H. K.; Yoo, B. C., (1998). The environmental impact of gold mines in the YuguKwangcheon Au-Ag metallogenic province Republic of Korea. Environ. Tech., 19, 291.

Kloke, A., (1979). Content of arsenic, cadmium, chromium, fluorite, lead, mercury and nickel in plants grown on contaminated soil. United Nations ECE Symp.

Lee, J. S.; Chon, H. T.; Kim, J. S.; Kim, K. W.; Moon, H. S., (1998). Enrichment of potentially toxic elements in areas underlain by black shales and slates in Korea. Environ Geochem. Hlth., 20 (30), 135-147 (13 pages).

Manjunatha, B. R.; Balakrishna, K.; Shanker, R.; Mahalingam, T. R., (2001). Geochemistry and assessment of metal pollution in soils and river India components of a monsoon -dominated environment near Karwar, southwest Coast. Environ. Geol., 40 (11-12), 1462-1470 (9 pages).

Manly, R., (1996). Biological indicators. Fifield, F. W., Haines, P. J. (Eds.). Environmental analytical chemistry. Black Academic and Professional, Oxford, London.

Mohiuddin, K. M.; Zakir, H. M.; Otomo, K.; Sharmoh, S.; Shikazono, N., (2010). Geochemical distribution of trace metal pollutants in water and sediments of downstream of an Urban river. Int. J. Environ. Sci. Tech., 7 (1) 17-28 (12 pages).

NIER, (2007). Investigation of the impact of mine discharges on Han-river watershed. $1^{\text {st. }}$ year's report.

Nishida, H.; Miyai, M., Tada, F.; Suzuki, S., (1982). Computation of the index of pollution caused by heavy metals in river sediment. Environ. Poll. Ser. B4: 241.

Olobaniyi, S. B., Owoyemi, F. B., (2006). Characterization by factor analysis of the chemical facies of ground water in the deltaic plain sands aquifer of Warri, Western Nigerdelta, Nigeria. Afr. J. Sci. Tech., 7 (1), 73-81 (9 pages).

Samarghandi, M. R.; Nouri, J.; Mesdaghinia, A. R.; Mahvi, A. H.; Naseri, S.; Vaezi, F., (2007). Efficiency removal of phenol, lead and cadmium by means of UV/TiO2/H2O2 processes. Int. J. Environ. Sci. Tech., 4 (1), 10-25 (16 pages).

Todd, D. K., (1980). Groundwater hydrogeology. John Willey and sons Inc., New York.

USEPA, (2007). Recent recommended water quality criteria. United States Environmental Protection Agency, http:// www.epa.gov/waterscience/criteria/wqcriteria.html 
USEPA, (2009). National Drinking water standards. United States Environmental Protection Agency, http:// www.epa.gov/safewater/

Wang, X.; Zhuo, Q., (2005). Ecotoxicological effects of cadmium on three ornamental plants. Chemosphere, 60 (1), 16-21 (6 pages).

Woodwell, G. M., (1972). A watch on the earth; Man's home series. United Nations Conference on the Human Environment. Stockholm, Sweden.

Zvinowanda, C. M.; Okonkwo, J. O.; Shabalala, P. N.; Agyei, N. M., (2009). A novel adsorbent for heavy metal remediationin aqueous environments. Int. J. Environ. Sci. Tech., 6 (3), 425-434 (11 pages).
AUTHOR (S) BIOSKETCHES
Odukoya, A. M., M.Sc., Ph.D., Lecturer, Department of Geosciences University of Lagos, Lagos, Nigeria. Email: sesanbiodun@yahoo.com

Abimbola, A. F., Ph.D., Associate Professor, Department of Geology University of Ibadan, Oyo, Nigeria. Email: bimbosah@yahoo.com

How to cite this article: (Harvard style)

Odukoya, A. M.; Abimbola, A. F., (2010). Contamination assessment of surface and groundwater within and around two dumpsites. Int. J. Environ. Sci. Tech., 7 (2), 367-376. 